\title{
Article
}

\section{Konrad H. Jarausch, Harald Wenzel and Karin Goihl (eds), Different Germans, Many Germanies: New Transatlantic Perspectives}

Copley, Clare

Available at http://clok.uclan.ac.uk/28240/

Copley, Clare ORCID: 0000-0002-7001-7604 (2019) Konrad H. Jarausch, Harald Wenzel and Karin Goihl (eds), Different Germans, Many Germanies: New Transatlantic Perspectives. Journal of Contemporary History, 54 (2). pp. 471-473. ISSN 0022-0094

It is advisable to refer to the publisher's version if you intend to cite from the work. http://dx.doi.org/10.1177/0022009418824807c

For more information about UCLan's research in this area go to http://www.uclan.ac.uk/researchgroups/ and search for <name of research Group>.

For information about Research generally at UCLan please go to http://www.uclan.ac.uk/research/

All outputs in CLoK are protected by Intellectual Property Rights law, including Copyright law. Copyright, IPR and Moral Rights for the works on this site are retained by the individual authors and/or other copyright owners. Terms and conditions for use of this material are defined in the policies page. 
Review: Konrad H. Jarausch, Harald Wenzel and Karin Goihl (eds.), Different Germans, Many

Germanies: New Transatlantic Perspectives, New York: Berghahn Books, 2017; viii +328 pp.; $£ 98$

hbk; ISBN 978-1-78533-430-6

\section{Dr Clare Copley}

$\underline{\text { University of Central Lancashire }}$

'What is the matter with these Germans?' This, according to Jarausch and Wenzel's introduction (p. 1), is the question asked by American political commentators struggling to make sense of German reactions to recent events such as the invasion of Iraq and the 2007-8 financial crisis. Meanwhile, entrapment in 'a negative perception of the past, failing to appreciate the degree to which Germany changed after 1945' delimits the capacity of many Anglo-American public intellectuals to help answer this question (p. 1). In a bid to address this, Goihl, Jarausch, Wenzel and their contributors 'explore neglected older traditions' in order to provide a more 'differentiated appreciation of the German experience than the stereotypical references that often dominate the media' (p. 15). The resulting edited volume draws together work-carried out, with one exception,-by alumni of the Berlin Program for Advanced German and European studies based at the Freie Universität Berlin. The programme's multi-disciplinary outlook is reflected in the range of the contributions to this edited collection, which includes insights gained from across Political Science, History and Cultural Studies.

This ambitious and wide-ranging volume is divided into four sections. Part One focuses primarily on Imperial and Weimar Germany. Here, the volume's overarching aim of elucidating Germany's complexity to American audiences is wonderfully framed through-Krause's chapter on American 
travel writers' perceptions of Wilhelmine Germany. The spread of ideas is traced both through Hansen's analysis of attempts to emulate and delimit the Southwestern dual training method elsewhere in Germany $y_{L}$ and through Wilson's work on the German forest ${ }_{\perp}$ in which he explores the contested nature of this symbol, which ostensibly unites the nation.

Part Two addresses post-war 'democratic transformation' across the two Germanies and includes Oberle's examination of the development of the 'myth of antifascism', Richardson-Little's chapter on the concept of 'human rights' in the GDR and Puaca's study of the battles for freedom of speech by student newspapers in post-war West Germany. Together, these chapters provide a fascinating insight into the processes and contests through which both the language and parameters of postwar 'freedom' came to be defined.

Part Three takes us through the post-unification period. Here, in-depth analyses by both Hager and Cassell provide the context needed to understand Germany's responses to contemporary problems; the development of renewable energy (Hager) and the 2008 financial crisis (Cassell). Their political science approach is nicely complemented by Jurgens' discussion of the complexity surrounding the incorporation of migrant narratives into 'majority German' memory culture. Part Four considers German-American encounters through chapters on US reception of early twentieth-century German film (Hall) and the critical theory of the Frankfurt School (Miller). Both of these insightful contributions highlight the contingent nature of transatlantic exchange through close analysis of political and institutional cultures. The section and, indeed, the volume as a whole, is concluded with Meng's thoughtful reflections on Germany's public memory of the Holocaust, highlighting the limits of 'redemptive' memory culture and the challenges of fostering genuinely 'reflective' memories (pp. $303-6)$.

The striking absence of the 1933 - 1945 period from the loosely chronologically-ordered contents page, explained by editors' decision 'not to include any chapters on the Nazi dictatorship' on the 
basis that 'the murderous policies of Hitler's Third Reich are already well-known to Anglo-American scholars' (p. 13), will doubtless set alarm bells ringing in some quarters. After all, consciously excluding any historical period in this way risks 'othering' it, or drawing accusations of historical revisionism,_and thus obscuring the wider connections that are fundamental to its scholarly interrogation. Yet these fears will be partially assuaged through the sensitive drawing out of these continuities and discontinuities within many of the contributing chapters. Particularly notable in this regard is Timm's work on the development of Germany's public health system. Taking US debates around 'socialised' medical provision as a pertinent starting point, Timm takes issue with scholarship and contemporary political commentary which, she argues, overlooks the progressive elements of the Imperial and Weimar state-funded health care system and focuses instead on its 'biopolitical totalitarianism'. Timm persuasively demonstrates that the Nazis' 'genocidal racial hygiene policies' (p. 98) should be considered a radicalisation of pre-existing health policy, not its inevitable outcome. Furthermore, the legacy of the Third Reich ripples through the concepts explored in much of the latter part of the book. For example, while not explicitly dealing with Nazism, Pugach provides a compelling insight into the enduring resonance of the politics of the past. In particular, she highlights the tension between the GDR's official stance on racism (that-the East German State was, unlike the FRG, 'antifascist, anti-imperialist and antiracist' (p. 190)) and the lived experience of black African exchange students during the 1960s.

The decision to move away from well-trodden terrain in favour of less-explored areas is certainly to be welcomed. However, this need not necessarily preclude contributions which take the 1933-45 period as their primary focus. After all, new dimensions of Third Reich and Holocaust studies are continually being developed by scholars from a range of disciplines, and the increasingly nuanced understanding of that period that these allow may be more effective in countering those dominant 'stereotypical references' that the editors have set out to challenge, rather than simply omitting it. 
That notwithstanding, this is a thought-provoking and innovative volume, which brings together well-written and insightful contributions from an eclectic range of scholars and incorporates their work into a coherent and compelling volume.

Elare Copley

University of Centraltancashire 